\title{
Production of bioethanol from sago hampas via Simultaneous Saccharification and Fermentation (SSF)
}

\author{
HUANG CHAI HUNG ${ }^{\bullet}$, DAYANG SALWANI AWANG ADENI, QUEENTETY JOHNNY, MICKY VINCENT ${ }^{\vee \bullet}$ \\ Faculty of Resource Science and Technology, Universiti Malaysia Sarawak. 94300 Kota Samarahan, Sarawak, Malaysia. Tel.: +60-82- \\ 582985, Fax.: +60-82-583160, ^email: abell.chaihung@ @otmail.com, ^^email: vmicky@unimas.my \\ Manuscript received: 14 September 2018. Revision accepted: 21 October 2018.
}

\begin{abstract}
Huang CH, Adeni DSA, Johnny Q, Vincent M. 2018. Production of bioethanol from sago hampas via Simultaneous Saccharification and Fermentation (SSF). Nusantara Bioscience 10: 240-245. Sago hampas is an inexpensive, renewable and abundant agro-industrial residue that can be exploited to produce bioethanol. In this study, ethanol production was performed via simultaneous saccharification and fermentation (SSF) on fresh sago hampas at $2.5 \%, 5.0 \%$ and $7.5 \%(\mathrm{w} / \mathrm{v})$ feedstock loadings with the aid of amylolytic enzymes, cellulolytic enzymes and Saccharomyces cerevisiae, under anaerobic condition for five days with a constant agitation of $150 \mathrm{rpm}$ and ambient temperature. Results obtained indicated that SSF with $5.0 \%$ (w/v) sago hampas loading produced the highest ethanol yield at $17.79 \mathrm{~g} / \mathrm{L}$ (79.65\% Theoretical Ethanol Yield, TEY), while SSF using 2.5\% and 7.5\% (w/v) sago hampas produced ethanol at only $8.38 \mathrm{~g} / \mathrm{L}(75.00 \% \mathrm{TEY})$ and $23.28 \mathrm{~g} / \mathrm{L}(69.48 \% \mathrm{TEY})$, respectively. Total biomass reduction was recorded between $66.3 \%$ to $71.3 \%$ by the end of the SSF period. This study demonstrated that fresh sago hampas is a promising feedstock for bioethanol production as yields are generally high for all the substrate loadings tested. Moreover, bioethanol production using fresh sago hampas may assist in reducing pollution caused by sago waste accumulation.
\end{abstract}

Keywords: Bioethanol, cellulose, enzymatic hydrolysis, sago hampas, simultaneous saccharification and fermentation, SSF

\section{INTRODUCTION}

Fuel demands from the transportation sector, which is the biggest user of diesel and gasoline, has increased tremendously in a worrying trend (Aditiya et al. 2016). These fossil-based fuels are not only non-renewable, but they are also not environmentally, ecologically or economically sustainable in a long term (Vincent et al. 2015a; Adekunle et al. 2016; Zabed et al. 2014). Therefore, alternative liquid biofuel, such as bioethanol, is currently being mass produced to substitute and supplement petroleum-based fuel due to its sustainability and carbon dioxide neutrality (Vincent et al. 2014). However, the current practices of using food and feed based feedstock, such as corn and sugar cane, are undesirable and controversial due to the concerns on food security (Daylan and Ciliz 2016). Therefore, the utilization of non-edible lignocellulosic materials for second-generation bioethanol production is capturing the attention of many researchers due to the restrictions in the use of food crops for firstgeneration bioethanol production as well as the high costs involved (Aditiya et al. 2016; Daylan et al. 2016).

Non-edible lignocellulosic materials are composed of cellulose, hemicellulose and lignin. These materials include waste streams from various sources such as food processing industries, forestry, agriculture, domestic and municipality origins. Additionally, starch is also found in several starchy-lignocellulosic biomasses such as cassava pulp, food waste and sago hampas (Behera et al. 2014; Thangavelu et al. 2016; Wan et al. 2016). These resources do not entirely compete with agricultural crops, and, are excellent candidates to be used as raw materials for bioethanol production (Tye et al. 2016).

Sarawak is the largest sago-growing region in Malaysia and has been recognized as the biggest sago starch exporter in the world. Sarawak exports approximately 44,000 tonnes of starch annually, mainly to Peninsular Malaysia, Japan and Singapore (Awg-Adeni et al. 2013). However, the production of this precious commodity also generates wastes, in the forms of organic rich effluent and solid residues called sago hampas, that are discarded into nearby streams, as well as deposited in the factory compound (Awg-Adeni et al. 2010). These practices have led to several environmental issues, such as water pollution and wastage of valuable resources (Wan et al. 2016). Sago hampas is made of 58\% starch, making it relatively easier and less expensive to process compared to another lignocellulosic biomass (Vincent et al. 2015b). It can be found in abundance in a typical sago starch processing plant where an estimated 7 tonnes of sago pith waste are generated daily (Awg-Adeni et al. 2010).

Therefore, in order to find a possible use for this misplaced solid residue, this study was performed to investigate bioethanol production from sago hampas at several loadings via simultaneous saccharification and fermentation (SSF) with the aid of commercial amylolytic and cellulolytic enzymes, in the presence of Saccharomyces cerevisiae. According to Vincent et al. (2015a), it is a preferred method for the production of second-generation bioethanol from lignocellulosic biomaterials. During SSF, resultant sugars liberated by the hydrolyzing enzymes are simultaneously metabolized by fermenting microorganisms 
to produce ethanol, thereby alleviating problems caused by product inhibition (Awg-Adeni et al. 2013; Kannan et al. 2013; Vincent et al. 2015b). Other advantage of using SSF include lower enzyme dosages, higher ethanol yields, lower requirement for sterile conditions, shorter processing time and cost reduction by eliminating expensive reaction and separation equipment (Jessen et al. 2012; Kang et al. 2014; Triwahyuni et al. 2015).

\section{MATERIALS AND METHODS}

\section{Characterization of sago hampas}

Sago hampas was collected from a local sago starch processing plant in Pusa, Sarawak (Malaysia). The sample moisture content was determined by weight loss from initial weight after oven drying at $105^{\circ} \mathrm{C}$ for 3 days. Prior to compositional analysis, sago hampas was destarched and dried for 3 days before it was ground to pass through a 1 $\mathrm{mm}(20 \mathrm{mesh}) \mathrm{screen}$ sieve. The samples were subjected to starch content and fibre analysis using phenol sulphuric acid assay, Acid Detergent Fibre (ADF), Neutral Detergent Fibre (NDF), Klason Lignin Determination according to Goering and van Soest (1970). Ash content was determined by ashing samples at $500^{\circ} \mathrm{C}$ for $24 \mathrm{~h}$. All analyses were performed in triplicates $(n=3)$.

\section{Saccharomyces cerevisiae culture preparation}

Saccharomyces cerevisiae ATCC 24859 culture inoculum for fermentation was prepared by growing the culture overnight in sterile Yeast Malt (YM) broth, in 250 $\mathrm{mL}$ conical flask with constant agitation at $120 \mathrm{rpm}$. The cell pellets were harvested through centrifugation in $50 \mathrm{~mL}$ falcon tube for $6 \mathrm{~min}$ at 4,500 rpm. After discarding the supernatants, the cells were added into the fermentation broth during the initial stages of the simultaneous saccharification and fermentation (SSF).

\section{Simultaneous Saccharification and Fermentation (SSF)}

SSF were performed in $500 \mathrm{~mL}$ Schott bottles with batch cultures of $200 \mathrm{~mL}$, consisting of $50 \mathrm{mM}$ Yeast Peptone Citrate Buffer (YP-CB) and sago hampas (2.5\%, $5.0 \%$ and $7.5 \% \mathrm{w} / \mathrm{v})$. The fermentation broth was autoclaved to provide sterility and to gelatinise the starch. After that, broths were kept in a $50{ }^{\circ} \mathrm{C}$ oven prior to the addition of amylases $(12.5 \mathrm{U} / \mathrm{mL}$ of $\alpha$-amylase; $25.0 \mathrm{U} / \mathrm{mL}$ of glucoamylase) and cellulase (50 FPU/g cellulose). Once the temperature of the fermentation broth had cooled down to ambient temperature, the harvested $S$. cerevisiae cells were inoculated aseptically. SSF was performed under anaerobic condition for five days with a constant agitation of $150 \mathrm{rpm}$ at ambient temperature. Sample aliquots of 1.5 $\mathrm{mL}$ samples were pipetted aseptically from each bottle at predetermined time intervals and centrifuged at 13,500 rpm for $5 \mathrm{~min}$. The supernatant was then filtered through 0.45 $\mu \mathrm{m}$ nylon syringe filter prior to analysis. At the end of fermentation period, the remaining biomass was centrifuged and dried for determination of biomass reduction.

\section{Phenol-sulphuric total carbohydrate assay}

The filtered supernatant was subjected to identify the total carbohydrate via phenol-sulphuric acid (PSA) assay (Crawfod and Pometto 1988). Colour formation in the PSA assay was determined by measuring absorbance against the reagent blank at $490 \mathrm{~nm}$ and the absorbance value was converted into equivalent values based on a standard curve constructed. All the analyses were performed in triplicate $(n=3)$.

\section{High Performance Liquid Chromatography (HPLC) analysis}

Filtered sample aliquots were also analysed using high performance liquid chromatography (HPLC) for residual glucose, maltose/cellobiose and xylose as well as fermentation products such as ethanol and acetic acid. The HPLC system (LC-20A, Shimadzu, Japan) used in this study was equipped with a column oven (CTO-20A, Shimadzu, Japan), refractive index detector (RID-10A, Shimadzu, Japan), isocratic pump (LC-20AT, Shimadzu, Japan) and computer controller. The separation and analysis of ethanol and other fermentation constituents were done on a Bio-Rad Aminex HPX-8711 column $(150 \times$ $7.8 \mathrm{~mm}$; Bio-Rad, CA, USA). Filtered aliquots of $20 \mu \mathrm{l}$ were injected into HPLC using $5 \mathrm{mM} \mathrm{H}_{2} \mathrm{SO}_{4}$ as the mobile phase, operating at a rate flow of $0.8 \mathrm{~mL} / \mathrm{min}$ and the column was heated to $65^{\circ} \mathrm{C}$ (Vincent et al. 2015b).

\section{RESULTS AND DISCUSSION}

\section{Characterization of sago hampas}

This study was conducted to utilize waste sago hampas to produce bioethanol via simultaneous saccharification and fermentation (SSF) at 2.5\%, 5.0\% and 7.5\% (w/v) solid loadings. Prior to the SSF process, compositional analyses were done on the sago hampas fibre. The results, as presented in Table 1, show that the main components in dried sago hampas are starch $(55.40 \pm 0.02 \%)$, cellulose $(23.64 \pm 0.77 \%)$, hemicellulose $(9.07 \pm 1.18 \%)$, lignin $(4.01 \pm 0.51 \%)$ and ash $(2.23 \pm 0.01 \%)$. The high percentages of starch and cellulosic components are comparable to the previous studies by Awg-Adeni et al. (2013), Thangavelu et al. (2014) and Vincent et al. (2015b), which were almost similar. These observations suggest that sago hampas is a choice material for amylo-cellulolytic hydrolyses to be further used downstream for ethanolic fermentation by fermenting microorganism such as S. cerevisiae (Arapoglou et al. 2010).

Table 1. Compositional analysis of sago hampas (as percentages based on dry weight; $n=3$ )

\begin{tabular}{lc}
\hline Chemical composition & \% w/w \\
\hline Starch & $55.4 \pm 0.02$ \\
Cellulose & $23.6 \pm 0.77$ \\
Hemicellulose & $9.1 \pm 1.18$ \\
Lignin & $4.0 \pm 0.51$ \\
Ash & $2.2 \pm 0.01$ \\
Others & $5.7 \pm 0.09$ \\
\hline
\end{tabular}




\section{Simultaneous saccharification and fermentation (SSF)}

Enzymatic saccharification is an important step prior to fermentation in yielding as much fermentation sugars as possible for the microbial conversion into ethanol. In this process, amylolytic enzymes, $\alpha$-amylase and glucoamylase were used as both $\alpha-1,4$ and $\alpha-1,6$ - debranching hydrolases efficiently break down gelatinized starch into maltose and glucose, for posterior saccharification and fermentation processes (Aydemir et al. 2014). These amylolytic enzymes act synergistically during the successive enzymatic saccharification of starch in accordance to several previously reported studies (Kannan et al. 2013; Diong et al. 2016). Later, cellulolytic enzymes, consisting mainly of $\beta$-1,4-endoglucanse, $\beta$-1,4-exoglucanse and $\beta$-glucosidase, were added to disrupt the solid fibre structure at the solidliquid interaction, making the individual fibres available for hydrolysis (Lakhundi et al. 2015).

\section{Phenol-sulphuric total carbohydrate assay}

Total carbohydrate concentration in this study was determined via phenol-sulphuric acid assay and the results are depicted in Figure 1. The initial total carbohydrates for $2.5 \%, 5.0 \%$ and $7.5 \%(\mathrm{w} / \mathrm{v})$ sago hampas loadings were $18.26,39.55$ and $56.53 \mathrm{~g} / \mathrm{L}$, respectively. Throughout the fermentation period, the total carbohydrates in the batch system of $2.5 \%(\mathrm{w} / \mathrm{v})$ feedstock loading decreased steeply in the first $6 \mathrm{~h}$ and then remained virtually constant. Meanwhile, the other two feedstock loadings decreased sharply in the first $12 \mathrm{~h}$. Based on the results obtained, experiments with $7.5 \%(\mathrm{w} / \mathrm{v})$ substrate showed the highest carbohydrates consumption of $87.0 \%$ (49.16 g/L) compared to the other substrate concentrations. However, residual carbohydrates were still detected in all fermentation media on the final day of SSF, indicating that not all resultant sugars were converted into ethanol.

\section{High performance liquid chromatography (HPLC) analysis}

To supplement the carbohydrate assay, the efficiency of enzymes in hydrolysing the sago hampas were gauged and validated through HPLC analysis for the presence of the main monomeric carbohydrate end products from starch and cellulose (Vincent et al. 2014). Figure 2 shows that the glucose concentration profiles were similar for the all feedstock loadings. The initial glucose production in the broth with $5.0 \%$ (w/v) sago hampas loading showed a twofold higher reading than $2.5 \%(\mathrm{w} / \mathrm{v})$ sago hampas loading, which was $34.72 \mathrm{~g} / \mathrm{L}$ compared to $18.29 \mathrm{~g} / \mathrm{L}$. However, at 0 $\mathrm{h}$, the glucose concentration in the broth with $7.5 \%(\mathrm{w} / \mathrm{v})$ sago hampas loading was valued at $42.83 \mathrm{~g} / \mathrm{L}$ only, due to the inefficient enzymatic saccharification of starch (Gupta et al. 2012; Vincent et al. 2015b). By 18 h, no glucose was detected in all broth samples; a good indication that efficient conversion of glucose into ethanol was achieved during fermentation.

Maltose/cellobiose are other saccharification products from starchy-cellulosic materials (Su et al. 2010; Bhaumik and Dhepe 2015). The initial maltose/cellobiose concentrations (Figure 3) were between 1.03 to $1.54 \mathrm{~g} / \mathrm{L}$ for all feedstock loadings. By $6 \mathrm{~h}$, early depletion of maltose/cellobiose was detected in the fermentation with $2.5 \%(\mathrm{w} / \mathrm{v})$ sago hampas loading. In contrast, maltose/cellobiose concentrations peaked at 2.22 and 2.74 $\mathrm{g} / \mathrm{L}$ for experiments with $5.0 \%(\mathrm{w} / \mathrm{v})$ and $7.5 \%(\mathrm{w} / \mathrm{v}) \mathrm{sago}$ hampas loads, respectively. The levels then decreased sharply until no maltose/cellobiose was further detected by $18 \mathrm{~h}$, demonstrating the effectiveness the enzymatic conversion of maltose/cellobiose to glucose and promptly into ethanol by yeast (Ferreira et al. 2010).

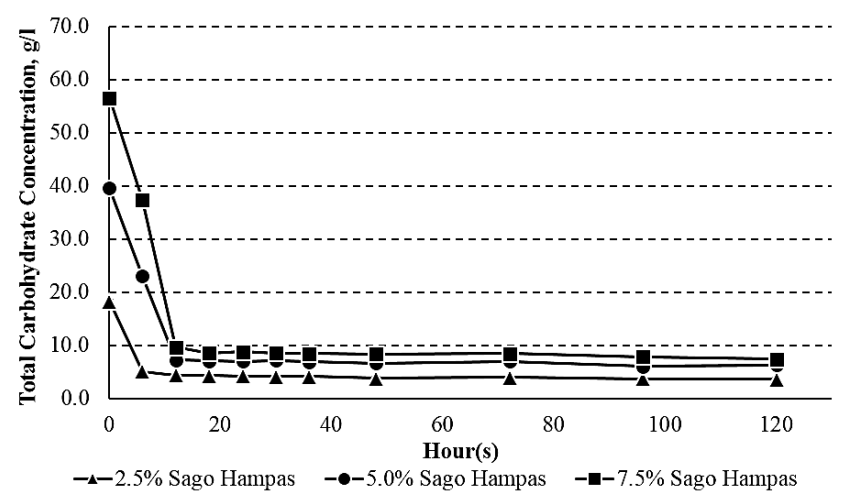

Figure. 1. Time course of total carbohydrate concentrations, as determined by the phenol-sulphuric acid assay $(n=3)$

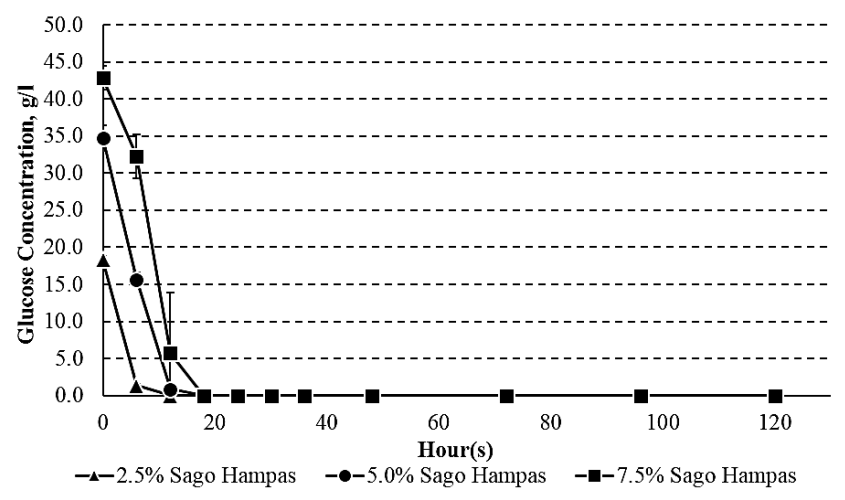

Figure 2. Time course of glucose concentrations, as determined via HPLC

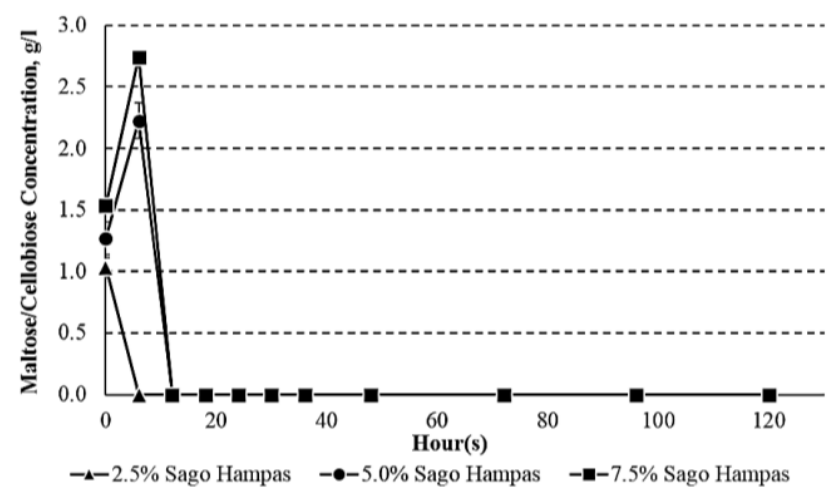

Figure 3. Time course of maltose/cellobiose profile during SSF, as determined via HPLC 
Effective enzymatic hydrolysis of a typical lignocellulosic material, such as sago hampas, can be gauged not only by the glucose and maltose/cellobiose profiles, but also by the amount of xylose released into the fermentation broth ( $\mathrm{Im}$ et al. 2016). This is anticipated as xylanases are part of the enzyme consortia used. The presence of xylanases is also vital as xylanases have synergetic effect on biomass hydrolyses by degrading heterogenous xylan polymers that surround cellulose microfibrils, resulting in enhanced hydrolyses of the overall lignocellulosic biomass (Wi et al. 2013). Figure 4 shows the xylose production profiles. In general, xylose production increased throughout the SSF period. These observations could be explained by the inability of $S$. cerevisiae to efficiently utilise xylose as a carbon source and its conversion into ethanol (Cassa-Barbosa et al. 2015; Srivastava et al. 2015).

The highest theoretical ethanol yield (TEY) was recorded in broth with $5.0 \%(\mathrm{w} / \mathrm{v})$ sago hampas loading at $79.65 \%$ or $17.79 \mathrm{~g} / \mathrm{L}$ at $48 \mathrm{~h}$ (Figure 5). This is significantly higher than TEY in the samples with $2.5 \%$ and $7.5 \%(\mathrm{w} / \mathrm{v})$ sago hampas loadings, which were $75.00 \%$ TEY (8.38 g/L) and 69.48\% TEY (23.38 g/L), respectively. For the experiment with $2.5 \%$ (w/v) sago hampas loading, ethanol concentration increased sharply to $75.00 \%$ TEY from 6 to $12 \mathrm{~h}$, decreasing marginally thereafter until $120 \mathrm{~h}$ to $62.38 \%$ TEY. At $7.5 \%$ (w/v) sago hampas loading, theoretical yield of bioethanol production increased sharply to $61.77 \%$ TEY from 0 to $12 \mathrm{~h}$, increasing slightly until reached its maximum ethanol production peaked at $48 \mathrm{~h}$.

Based on the TEY profile in Figure 5, one notable observation was that the differences in peak ethanol productions in all fermentation broths occurred inversely to the fermentable sugars concentrations present in the fermentation media, as reported elsewhere (Vincent et al. 2015a). The concentration of glucose (Figure 2) was higher at $7.5 \%(\mathrm{w} / \mathrm{v})$ sago hampas and longer duration was required for the $S$. cerevisiae to fully convert glucose to ethanol, while, the broth with $2.5 \%$ (w/v) sago hampas had lower fermentable sugars concentrations, requiring a shorter period for full conversion to ethanol. Ethanol production profile for the experiment with $5.0 \%(\mathrm{w} / \mathrm{v}) \mathrm{sago}$ hampas increased rapidly from 0 to $12 \mathrm{~h}$ (at $72.22 \% \mathrm{TEY}$ ) and remained at the range of $76.23 \%$ to $77.66 \%$ TEY. At $48 \mathrm{~h}$, ethanol production increased slightly to $79.65 \% \mathrm{TEY}$ but decreased to $63.06 \% \mathrm{TEY}$ at $120 \mathrm{~h}$. Additionally, the ethanol yield at $5.0 \%(\mathrm{w} / \mathrm{v})$ sago hampas loading in the present study was favourably comparable to those described in other previous studies (Kannan et al. 2013; Thangavelu et al. 2014; Vincent et al. 2015a, b).

Figure 6 shows the acetic acid production profiles. At $24 \mathrm{~h}$, acetic acid production in broth with $2.5 \%(\mathrm{w} / \mathrm{v})$ sago hampas peaked at $1.49 \mathrm{~g} / \mathrm{L}$, and, remained virtually constant until the end of the SSF period. Meanwhile, in the broth with $5.0 \%$ and $7.5 \%(\mathrm{w} / \mathrm{v})$ sago hampas, acetic acid increased steadily until $120 \mathrm{~h}$ to final concentrations of $1.85 \mathrm{~g} / \mathrm{L}$ and $2.07 \mathrm{~g} / \mathrm{L}$, respectively. One possible explanation for the increment in the rate of acetic acid production is the biological oxidation of ethanol. Additionally, the presence of acetic acid is also a vital indicator to gauge biomass hydrolysis, as the increase in acetic acid levels indicates continuous degradation of lignocellulosic materials during SSF (Vincent et al. 2015a).

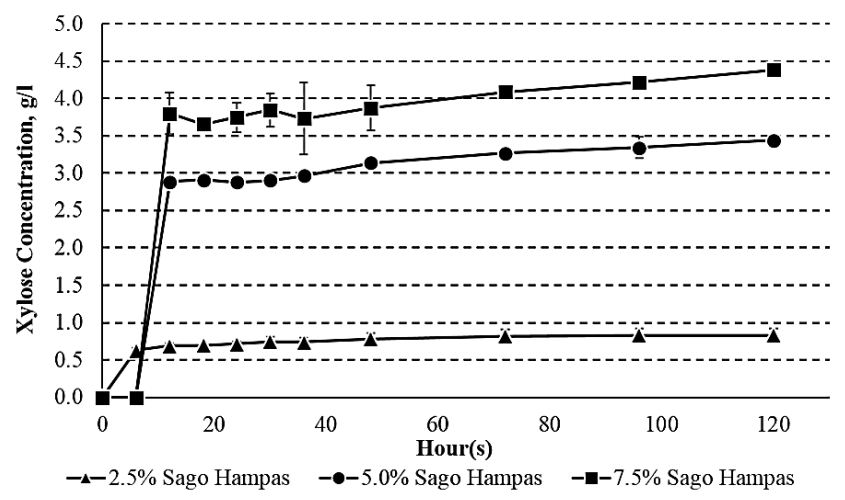

Figure 4. Time course of xylose profile during SSF, as determined via HPLC

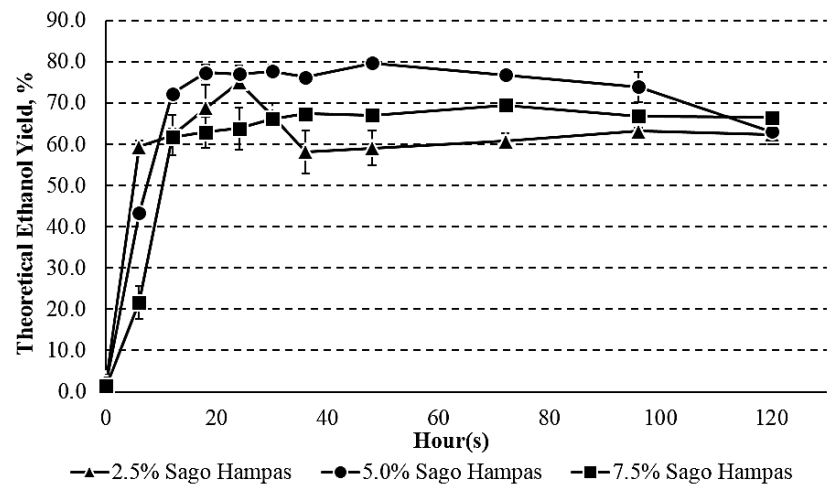

Figure 5. Time course of theoretical ethanol yield (TEY) profile during SSF

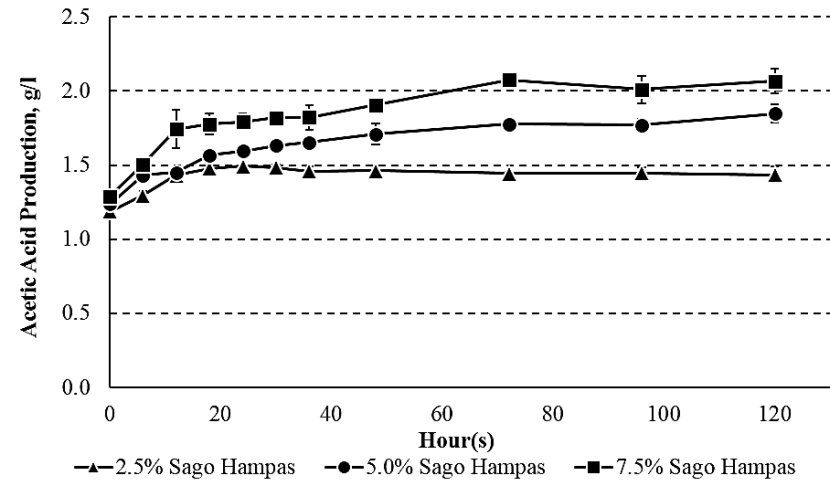

Figure 6. Time course of acetic acid profile during SSF, as determined via HPLC 


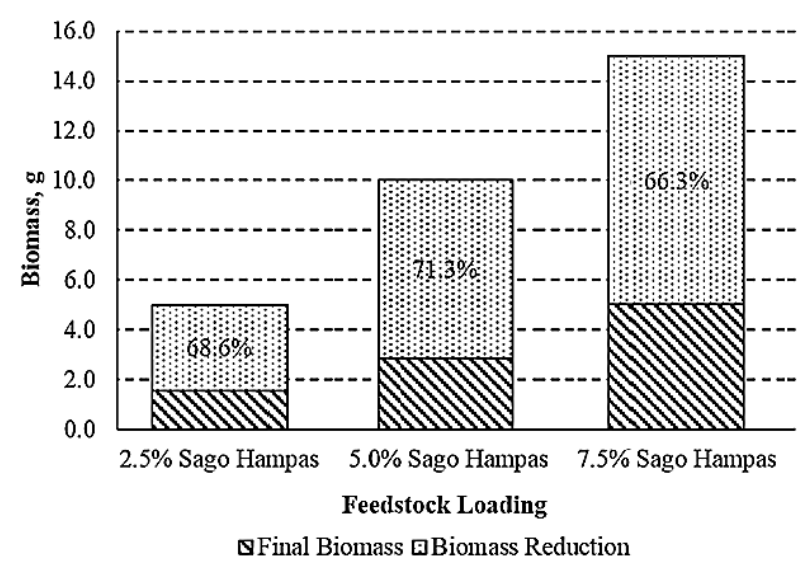

Figure 7. Biomass reduction of sago hampas after the SSF process

\section{Determination of biomass reduction}

By the end of the SSF period, total biomass reduction was recorded between $66.3 \%$ to $71.3 \%$ (Figure 7), indicating that less than $35.0 \%$ of the original substrate remained unutilised. These observations are encouraging as this study demonstrated that bioethanol production using fresh sago hampas may assist in reducing the environmental burden from the sago waste released by starch producing industries. Eventually, this may alleviate the needs for alternative waste management (Linggang et al. 2012; Kannan et al. 2013).

In conclusion, fresh sago hampas is shown to be a potential bioethanol feedstock when subjected to simultaneous saccharification and fermentation (SSF) with the aid of amylolytic-cellulolytic enzymes and $\mathrm{S}$. cerevisiae. The results showed that SSF with $5.0 \%(\mathrm{w} / \mathrm{v})$ sago hampas loading was the most effective in generating highest ethanol yield at $79.65 \%$ TEY.

\section{ACKNOWLEDGEMENTS}

This study was financial supported by the Malaysian Ministry of Higher Education (MOHE) Fundamental Research Grant Scheme grant [E14099-F07-69-1286/2015 (03)] and Tun Openg Sago Chair grant [F07/TOC/1518/2016].

\section{REFERENCES}

Adekunle A, Orsat V, Raghavan V. 2016. Lignocellulosic bioethanol: A review and design conceptualization study of production from cassava peels. Renew Sustain Energ Rev 64: 518-530.

Aditiya HB, Chong WT, Mahlia TMI, Sebayang AH, Berawi MA, Nur H. 2016. Second generation bioethanol potential from selected Malaysia's biodiversity biomasses: A review. Waste Manag 47: 4661.

Arapoglou D, Varzakas Th, Vlyssides A, Israilides C. 2010. Ethanol production from potato peel waste (PPW). Waste Manag 30 (10): 1898-1902.

Awg-Adeni DS, Abd-Aziz S, Bujang K, Hassan MA. 2010 Bioconversion of sago residue into value added products. African J Biotechnol 9 (14): 2016-2021.
Awg-Adeni DS, Bujang KB, Hassan MA, Abd-Aziz S. 2013. Recovery of glucose from residual starch of sago hampas for bioethanol production. BioMed Res Intl 2013: 935852. DOI: $10.1155 / 2013 / 935852$

Aydemir E, Demirci S, Doğan A, Aytekin AO, Sahin, F. 2014. Genetic modifications of Saccharomyces cerevisiae for ethanol production from starch fermentation: A review. J Bioproc Biotech 4 (7): 1-8.

Behera S, Arora R, Nandhagopal N, Kumar S. 2014. Importance of chemical pretreatment for bioconversion of lignocellulosic biomass. Renew Sustain Energ Rev 36: 91-106.

Bhaumik P, Dhepe PL. 2015. Conversion of biomass into sugars. In: Murzin, D, Simakova O. (eds) Biomass Sugars for Non-Fuel Applications. The Royal Society of Chemistry, United Kingdom.

Cassa-Barbosa LA, Procópio REI, Matos ITSR, Filho SA. 2015. Isolation and characterization of yeasts capable of efficient utilisation of hemicellulosic hydrolyzate as the carbon source. Genet Mol Res 14 (3): 11605-11612.

Crawford DL, Pometto AL. Acid-precipitable polymeric lignin: Production and analysis. Meth Enzymol 161: 35-47.

Daylan B, Ciliz N. 2016. Life cycle assessment and environmental life cycle costing analysis of lignocellulosic bioethanol as an alternative transportation fuel. Renew Energ 89: 578-587.

Diong KC, Ngoh GC, Chua ASM. 2016. Transformation of starchy lignocellulosic biomass to ethanol using ragi tapai synergized with microwave irradiation pretreatment. BioResources 11 (1): 1991-2006.

Ferreira V, Faber MdO, Mesquita SdS, Jr NP. 2010. Simultaneous saccharification and fermentation process of different cellulosic substrate using a recombinant Saccharomyces cerevisiae harbouring the $\beta$-glucosidase gene. Electr J Biotechnol 13 (2): 1-7.

Goering HK, van Soest PJ. 1970. Forage fiber analyses (apparatus, reagents, procedures, and some applications). Agricultural Handbook No. 379. United States Department of Agriculture, Washington, DC.

Gupta R, Kumar S, Gomes J, Kuhad RC. 2012. Kinetic study of batch and fed-batch enzymatic saccharification of pretreated substrate and subsequent fermentation to ethanol. Biotechnol Biofuels 5 (16): 1-10.

Im KH, Nguyen TK, Choi J, Lee TS. 2016. Ethanol production from various sugars and cellulosic biomass by white rot fungus Lenzites betulinus. Mycobiology 44 (1): 48-53.

Jessen JE, Orlygsson J. 2012. Production of ethanol from sugars and lignocellulosic biomass by Thermoanaerobacter $\mathrm{J} 1$ isolated from a Hot Springs in Iceland. J Biomed Biotechnol 2012: 1-7.

Kang Q, Appels L, Tan TW, Dewil R. 2014. Bioethanol from lignocellulosic biomass: Current findings determine research priorities. Sci World J 2014: 298153. DOI: 10.1155/2014/298153

Kannan TS, Ahmed AS, Ani FN. 2013. Energy efficient microwave irradiation of sago bark waste (SBW) for bioethanol production. Advan Mater Res 701: 249-253.

Lakhundi S, Siddiqui R, Khan NA. 2015. Cellulose degradation: A therapeutic strategy in the improved treatment of Acanthamoeba infection. Parasites Vectors 8 (1): 1-16.

Linggang S, Phang LY, Wasoh MH, Abd-Aziz S. 2012. Sago pith residue as an alternative cheap substrate for fermentable sugars production. Appl Biochem Biotechnol 167 (1): 122-131.

Srivastava N, Rawat R, Oberoi HS, Ramteke PW. 2015. A review on fuel ethanol production from lignocellulosic biomass. Intl J Green Energ 12 (9): 949-960.

Su MY, Tzeng WS, Shyu YT. 2010. An analysis of feasibility of bioethanol production from lignocellulosic biomass. Bioresour Technol 101 (17): 6669-6675.

Thangavelu SK, Ahmed AS, Ani FN. 2014. Bioethanol production from sago pith waste using microwave hydrothermal hydrolysis accelerated by carbon dioxide. Appl Energ 128: 277-283.

Thangavelu SK, Ahmed AS, Ani FN. 2016. Review on bioethanol as alternative fuel for spark ignition engines. Renew Sustain Energ Rev 56: $820-835$.

Triwahyuni E, Hariyanti S, Dahnum D, Nurdin M, Abimanyu H. 2015. Optimization of saccharification and fermentation process in bioethanol production from oil palm fronds. Procedia Chem 16: 141148.

Tye YY, Lee KT, Abdullah WNW, Leh CP. 2016. The world availability of non-wood lignocellulosic biomass for the production of cellulosic ethanol and potential pretreatments for the enhancements of enzymatic saccharification. Renew Sustain Energ Rev 60: 155-172.

Vincent M, Hambali NH, Esut E. 2014. Production of bioethanol from office waste via simultaneous saccharification fermentation. Bioremed Sci Technol Res 2 (1): 19-22. 
Vincent M, Jabang E, Nur NM, Esut E, Unting LB, Adeni DSA. 2015b. Simultaneous co-saccharification and fermentation of sago hampas for bioethanol production. Agric Eng Intl CIGR J 17 (2): 160-167.

Vincent M, Senawi BRA, Esut E, Nor NM, Adeni DSA. 2015a. Sequential saccharification and simultaneous fermentation (SSSF) of sago hampas for the production of bioethanol. Sains Malaysiana 44 (6): 899-904
Wan YK, Sadhukhan J, Ng DKS. 2016. Techno-economic evaluations for feasibility of sago-based biorefinery, Part 2: Integrated bioethanol production and energy systems. Chem Eng Res Design 107: 102-116.

Wi SG, Choi IS, Kim KH, Kim HM, Bae HJ. 2013. Bioethanol production from rice straw by popping pretreatment. Biotechnol Biofuels 6 (166): $1-7$.

Zabed H, Faruq G, Sahu JN, Azirum MS, Hashim R, Boyce AN. 2014. Bioethanol production from fermentable sugar juice. Sci World J 2014: 957102. DOI: 10.1155/2014/957102. 